TE RITA PAPESCH

\title{
A Māori Model of Leadership Practice
}

\section{Abstract}

He Waka Hiringa $(\mathrm{HWH})$ is a Masters of Applied Indigenous Knowledge offered as a programme of two years' study by Te Wānanga o Aotearoa. The main pre-requisite for enrolment in to this graduate degree is for the student to be a master of their own practice, whatever that practice may be. In other words, they are already leaders in their own field of practice. My task is to help them clarify how they indigenise their practice; introduce them to academic processes to achieve the rangahau (research) around this and encourage them to create their own Models of Practice (MsOP) to guide them as they work with students or clients.

In six years three cohorts of students have succesfully graduated through my encouragement in the development and approval of about 100 different new MsOP, each unique in its own way. These add to the use by graduates of HWH to models such as Whare Tapatoru ( Wi Te Tau Huata Snr. 1967, personal communication), Whare Tapawhā (Durie, M. 1984), Te Wheke (Pere, R. 1997) and Poutama Pōwhiri (Huata, P. 2011) to name a few well known MsOP. 
In terms of a Leadership MOP I have not seen a better model than that created by Te Wairere Te Pūāwaitanga o te Whakaaro Ngaia (my youngest child and daughter) to fulfil the requirements of her Masters in Management Communications and $\mathrm{Te}$ Reo Māori (Māori Language) graduate degree at The University of Waikato. I am going to use her MOP for leadership in competitive Kapa Haka ${ }^{1}$ (Māori performing arts) as my model in this delivery with her permission. The title comes from a waiata-āringa (action song) composed by one of her tuākana (older sisters), Te Ingo Karangaroa Ngaia, entitled 'He Rākau Taumatua!'2, for their whānau (family) kapa haka, Te Haona Kaha.

\section{The World of Academia and Leadership}

My invitation into the world of academia at a tertiary level came from an esteemed professor of mine, Tā Tìmoti Karetū. In 1986, heavily pregnant with my sixth child, Tìmoti urged me to apply for a Senior Tutor position (a Lectureship as it is now known) in the Department of Māori Studies at the University of Waikato. "Kei te hoa, he arohamutungakore mōu. E mārama ana koe ki te hōhonu o ngēnei kōrero ngāku." I had previously completed my B.A. Māori and Graduate Diploma of Teaching (Secondary) at this institution, and, after having been teaching in both the Hamilton and Auckland communities for

\footnotetext{
1 I use capital letters when talking about the art form and small letters when talking about a group that does the art form.

2 "He rākau taumatua" was first performed as a whakawātea by Te Haona Kaha kapa haka at the Tainui Waka Cultural Trust Regional Kapa Haka competitions in 2016.

${ }^{3}$ This is a personal greeting that I choose not to translate for this paper.
} 
some time, I was keen to get back to my 'Alma Mater', as they say. I quickly became comfortable in my teaching role in the Māori Department and felt that I was home, never to work anywhere else. Even though I spent most of my time in the Department teaching at Level 3 and Masters' courses, in both reo (language) and tikanga (customary practice) programmes, leadership opportunities were few and far between in the teaching space. At that time, the only theories or MsOP that we followed were steeped in mātauranga Māori (Māori knowledge and education) and mostly evolved from pūrākau Māori (Māori myths and legends) containing messages and examples of how we should live our lives.

In 1978 , when I was still a student, the competitive kapa haka (performing group) of Te Whare Wānanga o Waikato was formed. I had previously known Timoti and he was aware of my singing and performance abilities. Hence, I was named as female leader of the group without any consultation with the other members. His decision was not received well, initially, but as time went on I proved myself, the rest of the group warmed to me and we remain very close friends to this day. I held this position until I retired from competitive performance in 1994 after having had three more children. I remained as tutor for four more years but, now living and working in Christchurch, it was difficult for me to continue. I am proud to say, that for a time, my daughter Haani Huata succeeded me in this role.

The following year, 1979, our kapa haka represented the Waikato-Tainui region at Aotearoa Traditional Māori Performing Arts Festival (ATMPAF) and I was honoured to win the female leader's prize. This was the first time this position was recognised and the winner was accorded a Kākahu Kura 
(feathered cloak ), held until the next festival. When the following festival came around, at Avondale in 1981, I again won the female leader's prize. I had found my arena for leadership - Kapa Haka. This was, without a doubt, my happy place and although I no longer have the strength to endure a Haka performance I can manage one item!

Eventually I was to find a leadership space in academia at Canterbury University, becoming Head of Department and later on, when I returned to Waikato, Head of School at WINTEC. But, I had to leave home to achieve recognition by others as a leader in my field of work. This often seems to be the way with Māori. It is difficult to find a leadership space among your own iwi (tribe), at first. This usually comes when one is well into the twilight years or has spent some time away from home growing one's skills.

\section{A Model of Practice for Māori Leadership}

'He rākau taumatua, he karahuinga manu!'

'The birds flocked there because of the sweetness of the tree's fruit and nectar.' 


\section{TE RAKAU TAUMATUA}

"He rakau taumatua, he karahuinga manu" - Many birds flock to a great tree

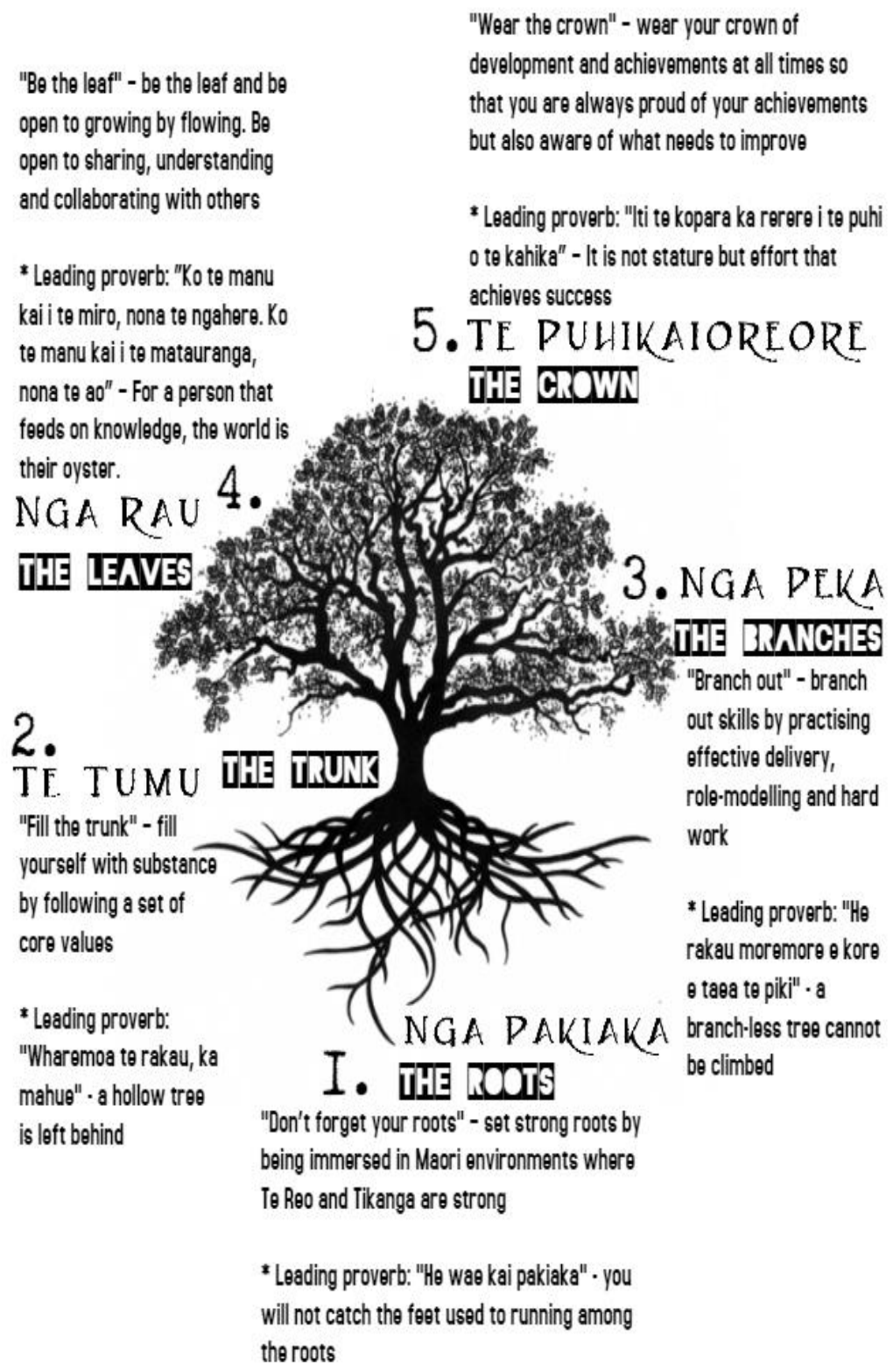


The underlying meaning of this whakataukī (Māori proverb) is that if you are a good leader your followers will be many and will continue to support you in their belief that what you stand for, how you conduct yourself, and what sacrifices you make, will lead them to achieve their main goals in life. They will come to you to be guided and led in the direction they want to go. What follows is another use of the whakatauki that fits with what I think every leader is tasked to do in order to grow their own 'flocks' to eventually become leaders themselves. Cowell, J (2013) states: This category refers to those who find value in the 'hua' (fruits, produce) and subsequently foster the growth of the seed to become itself a 'rākau taumatua'. (pp. 121,122)

Ngā Mātāpono - Guiding Principles

The following are commonly known concepts among most Māori but one cannot say all. Ngaia had introduced them in the order of importance that suited her MOP and which had also worked for her during her childhood and as she grew into an adult. For Ngaia this was everyday practice therefore she sought a model that would not take Māori too far out of their comfort zone while at the same time acknowledging the value and power of their own epistomology.

'He wai kai pakiaka.' 'Don't forget your roots!

\section{Te Reo me ngōna Tikanga}

Leading by example

Even though we, my siblings and I, a whānau of 10 children, had been raised to attend functions on our marae (gathering place) and tikanga were learnt 
tacitly, we never acquired a conversational reo. On the early death of our mother at the age of fifty-five, I felt that our last connection to te reo was lost. It was at this time that I made a commitment to learn te reo and bring it back into my own whānau (family) as a language of daily use. Myself and my five oldest children learnt te reo at the same time; I at University, they at secondary school, so we were our own community of speakers of te reo. Both Te Ingo and Te Wairere, my youngest surviving children, are native speakers of te reo with Te Ingo being our 'experiment' as I called her. Myself and her older siblings only spoke to her in te reo while her father spoke Pākehā. Eventually this rubbed off onto her father and he learnt te reo by listening and trying out what he heard. He is also now a fluent speaker of te reo having had little formal training.

\section{Māori worldview}

Thinking outside the square

In order to be an effective leader one needs to have the ability to think outside the square, to be ready for unforeseen eventualities. Having the ability to activate a Māori world view that can sit alongside a Pākehā world view, when the occasion requires it, is an extra tool in a leader's pocket. This allows the wider community that one works within to experience the value of a Māori world view that is all encompassing, and not exclusive. Nearly all Māori have Pākehā ancestry from somewhere else in the world and need to be open to incorporating that world view with their Māori world view to gain extra resilience to manage difficult situations that may arise. Having said that, I concentrated on cementing the knowledge and understanding of their Māori 
world view into my children via tacit, peripheral and taught learning. This meant using reo, applying tikanga and Kapa Haka (cultural performance, see p.2 Māori performing arts) being the daily norm for my children and consequently my grandchildren and great-grandchildren. A Pākehā world view was, and is, being presented to them on a daily basis via television and radio and when they walk out the door, so there is no need to expand into that space. Worldviews and culture, shape the identity of leaders. Henry, E. \& Wolfgramm, R. (2016) state: The study affirmed the ways in which culture and worldviews shaped the identity of these Māori leaders, confirming that relational leadership is a process of social construction, which emerges from the dynamic interaction between ontology (ways of being) and praxis (ways of doing). (p.1)

\section{Culture Ontology and Praxis}

Doing and being Māori

I hark back to the time when the establishment board of a Waikato region based Wharekura (secondary school) was consolidating their guiding kaupapa (reason for being). All the surveys that were conducted with prospective students and parents pointed to waka (Māori canoe) paddling and sailing and haka as being the desired cornerstones of ako (teaching and learning). Within these two disciplines, labelled by most as being culture in practise, one can learn maths, physics, engineering, science, te reo me ngōna tikanga, craft work such as sewing, weaving, carving, navigating by the stars and planting and harvesting food by the maramataka (Māori calendar). We had the bases of ako covered! Needless to say, the kapa haka of this 
Wharekura has excelled at the national secondary schools' Kapa Haka competition a number of times. Whitinui cites the following from Hindle and Van Rooyen (2002):

Students who are comfortable in their culture excel in their academic subjects. The educational importance of kapa haka is that Māori students have a valid learning approach to experiencing their language and culture through the art of moving and performing. (cited in Whitinui, P. 2008 p. 1)

\section{Whakapapa}

\section{Connections}

If one knows their whakapapa (genealogy), which tells them where they come from and who and what they belong to, they never go anywhere alone or do anything on their own. According to a Māori world view, as mentioned previously, they carry their whānau, extended whānau, hapū (sub tribe) and iwi with them. Therefore, Māori leaders never act independently and are always aware they represent many others and must conduct themselves accordingly. Nearly all Māori, via waka or iwi, are interconnected, hence the strength behind whakapapa in terms of leadership. Whakapapa is what brings us together.

"Wharemoa te rākau, ka mahue!" "Fill the trunk!"

Be three deep or more

My children and I, and most of my grandchildren now, are a band of trained warriors, soldiers. We are exponents of Māori weaponry use, both small and 
long rākau (sticks). All commanders of a war party need to have a line of soldiers three deep or more to hope for success in battle and to ensure completion of a task. I often hear my son, Raana, say to us when we are preparing to conduct a specific exercise beyond our safe space - Are we 'three deep', Māmā? - When I first asked him what he meant he responded with - Did we look left, then right, then left again, before crossing the road? Are we able to accomplish the task ahead to the best of our ability and with complete aforethought for others? MOB māmā! Maintain our benevolence! (Huata, R. personal communication 2021.) - In other words, do we have the back-up man power to accomplish the task ahead to the best of our abilities? It also means do you have the wealth of knowledge required in your field of expertise to be a good and productive leader so that your soldiers will follow you wherever you lead them?

Core Values/ Belief System

Maintaining benevolence sits at the heart of core values. For Māori, and it can be for all peoples, performing a task or implementing an idea from a space of aroha, of generosity should be what a leader aspires to do. Core values are the basis of any belief system and I am not talking about religions or faiths but a belief system that tells a person how to act in order to get the desired outcome.

"He rākau moremore e kore e taea te piki!" "Branch out!" 
Kete Mātauranga e toru. (The three baskets of knowledge.)

Depending on what pūrākau (myths and legends) are particular to your iwi, Tāwhaki ${ }^{4}$, or Tāne-nui-ārangi climbed the heavens to obtain the Kete Mātauranga - Tuatea, Aronui and Tuauri ${ }^{5}$. They are also known as Uruururangi, Uruurumatua, Uruurutau. Within these three kete lie all the information that Māori need to be able to call on to live their lives confidently on earth, between Ranginui (sky father) and Papatūānuku (earth mother) while also accessing the realm of those gone beyond, the wairua (spiritual realm), in a meaningful and productive manner. This principle encourages you to explore beyond what is immediately obvious and possible. Look for the probable! Do not be afraid to know a little bit about a lot! It is a great start to knowing a lot about a lot! Fill your three kete with as much general information as you can whether in offence of subject matter or defence. This will be what helps you achieve in your aspirations to lead.

\section{Clarity/ Role-modelling/ Work ethic}

When as a leader you give direction make sure it is done with clarity; that you as leader are seen to be role-modelling what you say to do and what will

\footnotetext{
4 Tāwhaki and Tāne-nui-ā-rangi in mythology are Māori departmental gods or super human beings.

5 Te Kete Tuatea is the experience we have of our connections with one another and with the past, Te Kete Aronui, contains the knowledge of our senses: what we experience in the world before us and Te Kete Tuauri, provides our understanding of what lies beyond our sensory experiences.
} 
then, hopefully, become evident is that you have a strong work ethic. All are attributes denoting a good leader.

"Ko te manu kai $i$ te miro, nōna te ngahere, ko te manu kai $i$ te mātauranga, nōna te ao." "Be the leaf!"

Levels of Mātauranga

When I first read the whakapākehā whakataukī (translated saying) of Te Wairere I had a little giggle to myself as I have heard young people saying it but did not quite grasp the meaning. Sitting alongside this often used whakatauāki (proverbial saying of encouragement) ka taka te kapa! (the penny dropped!). What she is saying is flutter around all over the place as a leaf is wont to do when blown by the wind. Be present in many situations in order to access learning of many different kinds from many different sources. Expose yourself to other people's viewpoints and try and understand them. Who knows what new gems of knowledge might lie within to guide you in your leadership space. Be willing to move out of your comfort zone to help others.

Sharing/ Understanding/ Collaborating

It is through the process of sharing, understanding what is being shared and being collaborative in the sharing that a leader can be present in many different situations, while contributing back to the whole, to the group that he or she leads. Not all good leaders have the same level of mātauranga (knowledge) in a particular area of activity that some of their group may have. It is in the sharing and collaboration of those different levels or stages of 
development of mātauranga that understanding comes and allows the group to move forward as needs be.

"Iti te kōpara, ka rērere I te puhi o kahika." "Wear the crown."

Don't inhibit your aspirations.

A crown is a visual representation of not only leadership but power. Not all people aspire to be leaders, or to have power over another fellow human being, even though everyone has the potential to be and do so within their own space of work and knowledge. Māori have a well-known whakataukī that states: Kāore te kūmara e kōrero ana mō tōna ake reka. (The kūmara doesn't talk of its own sweetness.) Unfortunately, this is a saying that stays with a person and along with the concept of whakamā (embarassment), (which some say is a left-over disposition from colonisation), can be responsible for inhibiting Māori from aspiring to leadership roles. Ross, M. (2018) says this about the whakataukī:

This well-known Māori proverb is an encouragement to be modest and conversely discourages people from being arrogant and pompous. I like the idea and have often heard the proverb used in casual and formal occasions to highlight how nice it is to be surprised by the understated nature of people, places, and events that you might come across. It also contrasts the ideal of ambition and a self-promoting culture where it is understood that unless you sell yourself, you won't gain opportunities. (p.1) 
However, selling yourself is part of the game one has to play in order to achieve a position of leadership. Just reflect on what prospective government members of parliament have to do in order to get a seat in the House of Parliament. They get out on the road and travel their constituency to sell themselves. But it is what one does when the crown has been placed on one's head that counts.

Effort/ Reflexivity/ Excellence

A good leader will be expected to expend a great amount of effort into a task in order to achieve the required outcome. They will also need to be reflexive, move from their own personal points of view to take on others' views which in turn expands their own Kete. A result of this is that that particular leader will be viewed as one who endeavours to excel in all spaces of leadership. "As leaders we need to find the clarity to truly see what is right in front of us. Only then will we deserve to "wear the crown!"'

\section{Conclusion}

In this paper, I have endeavoured to share my thoughts on what makes a good leader in today's society based on a Model of Practice created by Te Wairere Te Pūāwaitanga -o -te -Whakaaro Ngaia. The Model expresses and supports my views and beliefs on what leadership is from a Māori perspective. Although it works in the development and preparation of a kapa haka for competitive performance it can be used far more widely than that, in various other kaupapa.

Pai mārire! Hau! 


\section{References}

Cowell, J. (2103) 'He riri tā te tawa uho, he riri tā te tawa para.' An unpublised Master of Arts thesis. AUT.

Durie, M (1994) Whaiora, Māori health development. (pp. 67 - 81) Auckland. Oxford University press.

Henry, E. \& Wolfgramm, R. (2016) 'Relational Leadership: An Indigenous Māori perspective.' In 'Gender and Diversity: More Critical Perspectives. Book of Abstracts. Gender and Diversity Research Group. AUT.

Huata, P. H.T. (1997) Te Ngaru Learning Systems Books 1 - 5.

Huata, Wi Te Tau (snr) (1967) Personal Communication

Pere, R. (1991). Te Wheke: A celebration of infinite wisdom. Gisborne: Ao Ako Global Learning. New Zealand

Ross, M. (2018) Kāore te kumara e kōrero ana mō tōna reka. INDIGENOUS by MAI KI PONEKE JULY 20, 2018. Webinar series.

https://indigenousknowledgenetwork.net/2018/0

7/20/kaore-te-kumara-e-korero-mo-tonaake-reka-the-kumara-doesnt-speak-of-itsown-sweetness/ accessed April 7, 2021.

Whitinui, P. (2008) MAI Review, 2008, 3, Article 8 Kapa Haka counts: Improving participation levels of Māori students in mainstream secondary schools. University of Victoria, N.Z. 